\title{
Effects of Lime and Phosphorus Rates on Growth of Hybrid Arabica Coffee Seedlings at Jimma, Southwest Ethiopia
}

\author{
Ewnetu Teshale $^{1^{*}} \quad$ Taye Kufa $^{2} \quad$ Alemayehu Regassa ${ }^{3}$ \\ 1.Ethiopian Institute of Agricultural Research, Jimma Agricultural Research Center, P. O. Box 192, Jimma \\ Ethiopia \\ 2.International Institute of Tropical Agriculture- Burundi Station, P. O. Box 1893, Bujumbura \\ 3.Jimma University Department of Natural Resources Management \\ P.O.Box 307 Jimma, Ethiopia
}

\begin{abstract}
Coffee growing soil of southwestern region parts of Ethiopia are classified as Nitisols with having a low $\mathrm{pH}$ and highly deficient in phosphorus. $A$ nursery experiment was conducted at Jimma Agricultural Research Center, southwestern Ethiopia to evaluate the effects of lime and phosphorus rates on coffee seedling growth under nursery conditions. The experiment was laid out in a randomized complete block design with 3 replications. The treatments were arranged in factorial combinations of five levels of lime (0, 5, 10, 15 and $20 \mathrm{~g})$ and four levels of phosphorus (0, 400, 600 and $800 \mathrm{mg}) 2.5 \mathrm{~kg}^{-1}$ top soil. The statical data was analyzed through SAS software and treatment means were compared at 5\% probability using Duncan Multiple Range Test. The results revealed that the interactions of lime and P rates significantly increased the growth of both non-destructive parameters (plant height, girth, number of nods, interned length, leaf number and leaf area) and Root growth parameters (taproot length, lateral root length, lateral root number, root volume, leaf stem and root fresh weight, of coffee seedlings. The maximum shoot and root extensions were obtained from the interaction of $10 \mathrm{~g}$ lime and $800 \mathrm{mg}$ $P$ rates $2.5 \mathrm{~kg}^{-1}$ top soil. On the other hand, applications of $P$ significantly $(\mathrm{P} \leq 0.01)$ affected soil and plant growth parameters. As $\mathrm{P}$ rate increased availability $\mathrm{P}$ boosted and plant growth were enhanced. Similarly, an application of lime significantly affected $(\mathrm{P} \leq 0.01)$ plant growth and enhance nutrient availability up to $10 \mathrm{~g}$, though further applications adversely affect seedling growth and nutrient availability. Hence, combined application of $10 \mathrm{~g}$ lime and $800 \mathrm{mg} P$ rate $2.5 \mathrm{~kg}^{-1}$ top enhances the optimum growth of coffee seedlings under nursery conditions.
\end{abstract}

Keywords: Coffee nursery, Coffee seedlings, Exchangeable acidity, Lime rates

DOI: $10.7176 / \mathrm{JBAH} / 9-15-04$

Publication date: August $31^{\text {st }} 2019$

\section{Introduction}

In Ethiopia currently about $40 \%$ of the total arable land was affected by soil acidity, out of this about $27.7 \%$ is moderately acidic and $13.2 \%$ is strongly acidic (Adane, 2015). As a result, most of the soils have a pH range of 4.5 to 5.5 and contain low organic matter and also low nutrient availability (Achalu, 2014).

Ethiopia is one of the largest coffee producer in Africa and is the sixth largest coffee producer in the world next to Brazil, Vietnam, Colombia, Indonesia and Hondura, contributing about 4.1 percent of total world coffee production (ICO, 2018). Moreover, it has tremendous impact on economic, social and spiritual life of people of the country and, quarter of the population of the nation to depend directly or indirectly on coffee for its income generation (Girma et al., 2008). According to CSA (2017), the estimated area of land covered by coffee in Ethiopia is about 700,474.69 hectares, whereas the estimated annual national production of clean coffee is about $469,091.12$ tons and mainly produced in the southwestern and southeastern parts of the country. At present, Ethiopia has 40 improved (34 varieties and 6 hybrids) and released coffee berry disease (CBD) resistant varieties (Tadesse, 2017).

The bulk of coffee soils in the southwestern region are classified as Nitisols, which are highly weathered and originate from volcanic rock and this soils are deep and well drained having a low $\mathrm{pH}$ and highly acidic in nature, and have medium to high contents of most of the essential elements and highly deficient in phosphorus (Paulos, 1994; Smithson, 1999; Anteneh, 2015b). Despite there are about 200 million ha of Nitisols which affected by soil acidity problems at worldwide about one million hectares that account for $31 \%$ of the agricultural lands in the Ethiopian highlands (Eyasu, 2017).

Increased soil acidity causes solubilization of aluminum, which is the primary source of toxicity to plants at $\mathrm{pH}$ below 5.5, and deficiencies of $\mathrm{P}, \mathrm{Ca}, \mathrm{Mg}, \mathrm{Mo}, \mathrm{N}, \mathrm{K}$, and micronutrients (Habtamu, 2015). Therefore, in addition to $\mathrm{Al}^{3+}$ toxicity, low $\mathrm{P}$ availability to crops is also another factor limiting crop production on acid soils (Kabata, 2001; Abdena, 2013).

Top soil of Nitisol with lime and phosphorus fertilizer was an alternative nursery media for improved selection coffee cultivars of coffee seedling which enhances to produced higher dry matter, healthy and vigorous seedlings for transplanting. This was primarily associated to the rise in soil $\mathrm{pH}$ and precipitation of the 
exchangeable $\mathrm{Al}^{3+}$ that fixes phosphorous and increase in solubility and availability of soil phosphorus to the seedlings (Anteneh and Heluf, 2007; Anteneh 2015c). The aim of this work was to evaluate the responses of lime and phosphorus for alleviating soil acidity and optimum hybrid coffee seedlings growth under nursery condition.

\section{Materials and Methods}

\subsection{Description of the Study Area}

The study was conducted at Jimma Agricultural Research Center (JARC) nursery site. The center is located in Jimma zone Oromiya Regional State, Southwest Ethiopia at a distance of $365 \mathrm{~km}$ from Addis Ababa and $12 \mathrm{~km}$ from Jimma Town. Geographically lies between $7^{0} 46^{\prime} \mathrm{N}$, latitude $36^{\circ} 47^{\prime} \mathrm{E}$ longitudes at an altitude 1750 meter above sea level. The mean annual rain fall recorded $1532 \mathrm{~mm}$ and the min and maximum temperature are about $11.73^{\circ} \mathrm{c}$ and $26.11^{\circ} \mathrm{c}$ respectively. Nitisols are the dominant reference soil groups in the upper slopes and Planosols in the low lying plain areas (DeWispelaere et al., 2015).

\subsection{Experimental Materials}

Liming material calcium carbonate $\left(\mathrm{CaCO}_{3}\right)$ which contains $98 \%$ neutralizing values, fertilizers Triple Super Phosphate $\left(46 \% \mathrm{P}_{2} \mathrm{O}_{5}\right)$ and urea $(46 \% \mathrm{~N})$ were used. Hybrid coffee variety- Gawe used as a test crop. The variety was released in year 2002 and recommended for medium altitude coffee growing areas (Desalegn, 2017). Among all coffee varieties, Gawe was the $2^{\text {nd }}$ leading variety in terms of yield performance under research and on-farm field conditions with high quality standard (Tadesse, 2017). For this, ripe red cherries was handpicked at JARC and prepared properly following the standard procedures (Yacob et al., 1996)

\subsection{Experimental Procedures}

The different lime rates as powdered lime having a calcium carbonate equivalent of $98 \%$ were weighted and thoroughly mixed with $2.5 \mathrm{~kg}$ of the sieved soil. Lime was applied one month before sowing for better incubation as described by Achalu et al.( 2012) Thereafter, the soil blended potting media was filled in black polythene bags of $16 \mathrm{~cm}$ wide and $22 \mathrm{~cm}$ long and each experimental unit which consist of 16 pots. The prepared seeds from the hybrid coffee variety (Gawe) were sown at the rate of two seeds per pot and thinned to one seedling after the germinated seeds attained a butterfly growth stage. Whereas, phosphorus was applied as triple super phosphate $\left(46 \% \mathrm{P}_{2} \mathrm{O}_{5}\right)$ once when the seedlings attained a butterfly stage, while recommended rate of 540 mg $\mathrm{N}$ was applied as urea $(46 \% \mathrm{~N})$ in three equal splits, i.e., when the seedlings attained butterfly stage, two and four pairs of true leaves as described by Anteneh (2015b). All the routine pre-and post-sowing nursery practices were applied according to the recommendation (Tesfaye et al., 2005).

\subsection{Data collected}

Four uniform seedlings in the inner part of each plot were selected when seedlings growth attained for transplanting (six pair of leave) used as representative sample to collect data as described below.

\subsubsection{Shoot growth parameter}

Plant height $(\mathrm{cm})$ : The length of newly developed shoots of the samples was measured from the base to the tip of the shoot using a ruler and the average of plot was taken from each treatment

Girth (mm): Girth of the stem was measured at the base near a medium surface using caliper

Number of leaves: Total number of seedling was counted

Number of node: Number of node per seedling was counted

Leaf area $\left(\mathrm{cm}^{2}\right)$ : Leaf length from petiole to the tip and leaf width at broadest part was measured. Then, intact leaf area per leaf was calculated using the protocol adapted by Yakob et al. (1998)

$$
\mathrm{Y}=\mathrm{K} * \mathrm{~L} * \mathrm{~B}
$$

Where, $\mathrm{Y}=$ estimated leaf area

$\mathrm{K}=$ constant specific to cultivars and canopy class $(0.67)$

$\mathrm{L}=$ Leaf length $(\mathrm{cm})$

$\mathrm{B}=$ maximum leaf breadth $(\mathrm{cm})$

Shoot fresh and dry weights (g):- After measuring leaf and stem fresh weights, the same shoot samples were kept in an oven drier (at the temperature of $70{ }^{\circ} \mathrm{C}$ to constant weight for $24 \mathrm{hrs}$. to record dry weights using a sensitive balance and shoot moisture content was calculated from each treatment

\subsubsection{Root characteristics}

The same four central seedlings were used to record root parameters. Root characteristics was recorded subsequent to the separation of medium from the roots to this end the polythene bags containing the seedlings was immersed in a bucket of water where roots was carefully separated. The roots were washed in clean water and the following root characteristics were recorded.

Root fresh weight (g): Roots was carefully detached and thoroughly washed to remove the soil then weight was 
measured using sensitive balance

Tap root length $(\mathbf{c m})$ : The length between the collar region and the tip of the primary root was measured and the mean value was recorded by using ruler

Lateral root numbers and length: The numbers of lateral root were counted and length were measured by using ruler

Root volume (ml):- Measured by water displacement method using graduated cylinder half filed with water. The volume of water displaced due to the immersion of each sample was calculated and the average was taken as root volume

Root dry weights (g):- Root fresh weight was measured and immediately put in an oven drier (at the temperature of $70{ }^{\circ} \mathrm{C}$ to constant weight) for $24 \mathrm{hrs}$. Root weights were measured using a sensitive balance and the average was calculated from each treatment

\subsubsection{Experimental design and Statistical Analysis}

Five lime rates $0,5,10,15$ and $20 \mathrm{~g} 2.5 \mathrm{~kg}^{-1}$ and four phosphorus mineral fertilizer rates $0,400,600$ and $800 \mathrm{mg}$ $2.5 \mathrm{~kg}^{-1}$ were used. The amount of lime applied at each was calculated on the basis of exchangeable acidity concentration of the soil and crop factor tolerant to soil acidity (Kamprath, 1984; Kebede and Dereje, 2017).The study was conducted in $5 \times 4$ factorial experiment arranged in a randomized complete block design with three replications. All the relevant data was summarized and subjected to analysis of variance (ANOVA) using the General Linear Model of SAS 9.2 version. Treatment means were separated using Duncan multiple range test at $5 \%$ probability level for significantly different parameters (SAS institute, 2004).

Table 1.Treatment combination and descriptions

\begin{tabular}{|c|c|}
\hline $\begin{array}{l}\text { Treatment } \\
\text { No }\end{array}$ & $\begin{array}{c}\text { Treatment combinations } \\
\text { (Lime and } P \text { rates } 2.5 \mathrm{~kg}^{-1} \text { soil) }\end{array}$ \\
\hline 1 & 0gm Lime and $0 \mathrm{mg}$ Phosphorus (Control) \\
\hline 2 & 0gm Lime and $400 \mathrm{mg}$ Phosphorus \\
\hline 3 & 0gm Lime and $600 \mathrm{mg}$ Phosphorus \\
\hline 4 & 0 gm Lime and $800 \mathrm{mg}$ Phosphorus \\
\hline 5 & $5 \mathrm{gm}$ Lime and $0 \mathrm{mg}$ Phosphorus \\
\hline 6 & $5 \mathrm{gm}$ Lime and $400 \mathrm{mg}$ Phosphorus \\
\hline 7 & 5 gm Lime and $600 \mathrm{mg}$ Phosphorus \\
\hline 8 & 5gm Lime and $800 \mathrm{mg}$ Phosphorus \\
\hline 9 & $10 \mathrm{gm}$ Lime and $0 \mathrm{mg}$ Phosphorus \\
\hline 10 & $10 \mathrm{gm}$ Lime and $400 \mathrm{mg}$ Phosphorus \\
\hline 11 & $10 \mathrm{gm} \mathrm{Lime} \mathrm{and} 600 \mathrm{mg}$ Phosphorus \\
\hline 12 & $10 \mathrm{gm}$ Lime and $800 \mathrm{mg}$ Phosphorus \\
\hline 13 & $15 \mathrm{gm}$ Lime and $0 \mathrm{mg}$ Phosphorus \\
\hline 14 & $15 \mathrm{gm}$ Lime and $400 \mathrm{mg}$ Phosphorus \\
\hline 15 & 15 gm Lime and $600 \mathrm{mg}$ Phosphorus \\
\hline 16 & $15 \mathrm{gm}$ Lime and $800 \mathrm{mg}$ Phosphorus \\
\hline 17 & $20 \mathrm{gm}$ Lime and $0 \mathrm{mg}$ Phosphorus \\
\hline 18 & $20 \mathrm{gm}$ Lime and $400 \mathrm{mg}$ Phosphorus \\
\hline 19 & $20 \mathrm{gm}$ Lime and $600 \mathrm{mg}$ Phosphorus \\
\hline 20 & $20 \mathrm{gm}$ Lime and $800 \mathrm{mg}$ Phosphorus \\
\hline
\end{tabular}

\section{Result and Discussions}

\subsection{The Shoot Growth of Coffee Seedlings}

Lime and phosphorus and their interactions had significant effects $(P \leq 0.01)$ on coffee seedling height, girth and internode length (Table 2). The maximum seedling height $11.87 \mathrm{~cm}$, girth $3.26 \mathrm{~mm}$ and internode length $1.61 \mathrm{~cm}$ recorded from the plots $10 \mathrm{~g}$ lime and $800 \mathrm{mg} \mathrm{P}$ rates respectively. A combination of lime and phosphorus fertilizer resulted to vigorous plant height than that with lime or P used independently (Table 2). The result was in agreement with Uzoho et al. (2010) which reported that lime and phosphorus promote plant growth through improved soil conditions such as increased soil $\mathrm{pH}$, nutrient availability, soil organic matter, soil solution $\mathrm{P}$ concentration and decreased aluminum toxicity and micronutrient accumulation.

It is noted that the application of phosphorus resulted in a linear increase of the ratio stem height and stem diameter (girth). Treatment effectiveness on seedlings height, girth and internode length generally increased in the order control, lime, $\mathrm{P}$ fertilizer, $\mathrm{P}$ fertilizer + lime. This was due to the fact that, lime alleviated plants from $\mathrm{Al}$ toxicity, reduced $\mathrm{P}$ fixation and increase $\mathrm{Ca}$ and $\mathrm{P}$ availabilities described by The et al. (2006). In agreement with this result, Kisinyo et al. (20014) indicated that growth of plant enhanced in acidic soil with additions lime and $\mathrm{P}$ fertilizers. 
Table 2.The interaction effects of lime and phosphorus rates on the shoot growth of hybrid coffee seedlings

\begin{tabular}{|c|c|c|c|c|}
\hline No & Treatment & Plant height & Stem girth & Internode length \\
\hline $\mathbf{T}_{1}$ & Control & $7.63^{\mathrm{kl}}$ & $2.46^{\mathrm{fg}}$ & $1.15^{\mathrm{h}}$ \\
\hline $\mathbf{T}_{2}$ & 0gm Lime and $400 \mathrm{mg}$ phosphorus & $9.80^{\mathrm{gf}}$ & $2.47^{\text {fg }}$ & $0.98^{\mathrm{ji}}$ \\
\hline $\mathbf{T}_{3}$ & 0gm Lime and $600 \mathrm{mg}$ phosphorus & $10.97^{\text {bcd }}$ & $2.77^{\mathrm{d}}$ & $1.32^{\text {def }}$ \\
\hline $\mathbf{T}_{4}$ & 0 gm Lime and $800 \mathrm{mg}$ phosphorus & $11.37^{\mathrm{ba}}$ & $3.06^{\mathrm{bc}}$ & $1.41^{\mathrm{dc}}$ \\
\hline $\mathbf{T}_{5}$ & $5 \mathrm{gm} \mathrm{Lime} \mathrm{and} 0 \mathrm{mg}$ phosphorus & $8.97^{\text {ih }}$ & $2.88^{\mathrm{dc}}$ & $1.17^{\mathrm{hg}}$ \\
\hline $\mathbf{T}_{6}$ & $5 \mathrm{gm}$ Lime and $400 \mathrm{mg}$ phosphorus & $9.33^{\text {gh }}$ & $2.75^{\text {de }}$ & $1.29^{\mathrm{ef}}$ \\
\hline $\mathbf{T}_{7}$ & 5 gm Lime and $600 \mathrm{mg}$ phosphorus & $10.47^{\text {efd }}$ & $2.86^{\mathrm{dc}}$ & $1.38^{\mathrm{de}}$ \\
\hline $\mathbf{T}_{8}$ & $5 \mathrm{gm}$ Lime and $800 \mathrm{mg}$ phosphorus & $11.27^{\mathrm{ba}}$ & $3.15^{\text {ba }}$ & $1.57^{\mathrm{ba}}$ \\
\hline $\mathbf{T}_{9}$ & $10 \mathrm{gm}$ Lime and $0 \mathrm{mg}$ phosphorus & $10.27^{\mathrm{ef}}$ & $3.11^{\mathrm{ba}}$ & $1.40^{\mathrm{d}}$ \\
\hline $\mathbf{T}_{10}$ & 10 gm Lime and $400 \mathrm{mg}$ phosphorus & $11.13^{\mathrm{bc}}$ & $2.92^{\mathrm{dc}}$ & $1.41^{\mathrm{dc}}$ \\
\hline $\mathbf{T}_{11}$ & $10 \mathrm{gm}$ Lime and $600 \mathrm{mg}$ phosphorus & $11.60^{\mathrm{ba}}$ & $3.14^{\text {ba }}$ & $1.50^{\mathrm{bc}}$ \\
\hline $\mathbf{T}_{12}$ & $10 \mathrm{gm}$ Lime and $800 \mathrm{mg}$ phosphorus & $11.87^{\mathrm{a}}$ & $3.26^{\mathrm{a}}$ & $1.61^{\mathrm{a}}$ \\
\hline $\mathbf{T}_{13}$ & 15 gm Lime and $0 \mathrm{mg}$ phosphorus & $8.10^{\mathrm{kj}}$ & $1.88^{\mathrm{i}}$ & $1.03^{\mathrm{i}}$ \\
\hline $\mathbf{T}_{14}$ & $15 \mathrm{gm}$ Lime and $400 \mathrm{mg}$ phosphorus & $9.30^{\mathrm{gh}}$ & $2.36^{\mathrm{g}}$ & $1.16^{\mathrm{hg}}$ \\
\hline $\mathbf{T}_{15}$ & 15 gm Lime and $600 \mathrm{mg}$ phosphorus & $10.03^{\mathrm{ef}}$ & $2.57^{\mathrm{fe}}$ & $1.26^{\mathrm{gf}}$ \\
\hline $\mathbf{T}_{16}$ & 15 gm Lime and $800 \mathrm{mg}$ phosphorus & $10.60^{\mathrm{ecd}}$ & $2.87^{\mathrm{dc}}$ & $1.35^{\mathrm{def}}$ \\
\hline $\mathbf{T}_{17}$ & $20 \mathrm{gm}$ Lime and $0 \mathrm{mg}$ phosphorus & $7.20^{1}$ & $1.69^{j}$ & $0.82^{\mathrm{k}}$ \\
\hline $\mathbf{T}_{18}$ & $20 \mathrm{gm}$ Lime and $400 \mathrm{mg}$ phosphorus & $7.73^{\mathrm{kl}}$ & $2.01^{\mathrm{ih}}$ & $0.87^{\mathrm{k}}$ \\
\hline $\mathbf{T}_{19}$ & 20 gm Lime and $600 \mathrm{mg}$ phosphorus & $8.20^{1 \mathrm{k}}$ & $2.17^{\mathrm{h}}$ & $0.91^{\mathrm{jk}}$ \\
\hline \multirow[t]{3}{*}{$\mathbf{T}_{20}$} & $20 \mathrm{gm}$ Lime and $800 \mathrm{mg}$ phosphorus & $8.50^{\mathrm{ij}}$ & $2.50^{\mathrm{fg}}$ & $1.02^{\mathrm{i}}$ \\
\hline & $\mathbf{S E M} \pm$ & $\mathbf{0 . 0 3 7}$ & 0.012 & 0.006 \\
\hline & CV (\%) & 3.48 & 4.21 & 4.27 \\
\hline
\end{tabular}

Different letters within a column represent significant differences at $5 \%$ level

Lime and phosphorus and their interactions had significant effects $(P \leq 0.01)$ on coffee seedling number of nodes, leaf number and leaf area (Figures 1, 2 and 3). The maximum seedlings number of nodes 5.63, leaf number 11.42 and leaf area $13.62 \mathrm{~cm}^{2}$ were recorded from the plots $10 \mathrm{~g}$ lime and $800 \mathrm{mg} \mathrm{P}$ rates respectively. Although additions of lime up to $10 \mathrm{~g}$, improved number of nodes 5.42, leaf number 11.00 and leaf area 10.63 $\mathrm{cm}^{2}$ and respectively (Fig 1, 2 and 3). However the increasing rates of lime from 15 to $20 \mathrm{~g}$ seedling number of nodes, leaf number and leaf area decreased dramatically (Fig 1, 2 and 3).

This is due to that increased amount of exchangeable calcium that contributed to the rising of soil $\mathrm{pH}$, reduce micro nutrients needed in small amount by the plant such as iron and manganese, and also declined the availability of p nutrient (Kebede and Dereje, 2017).

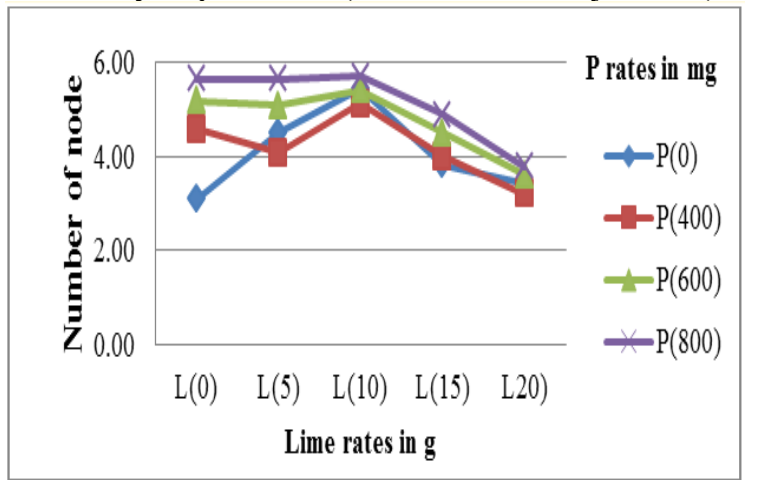

Fig 1 The interaction effects of lime and $\mathrm{P}$ rates on node numbers of hybrid coffee seedlings

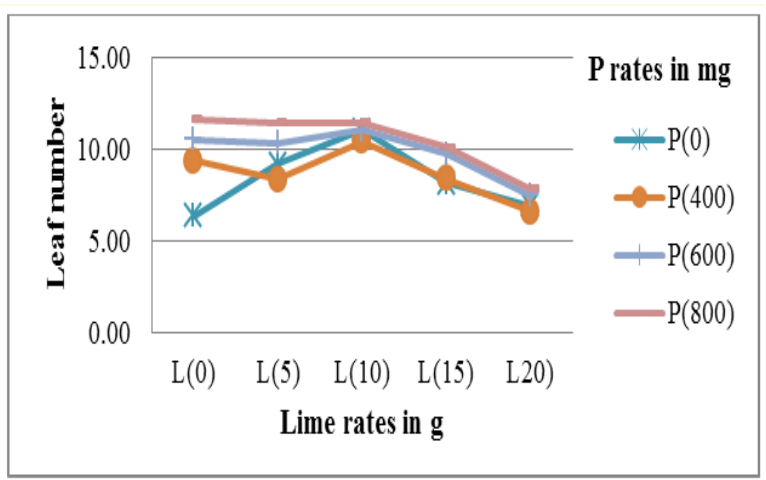

Fig 2 The interaction effects of lime and P rates on leaf number of hybrid coffee seedlings 


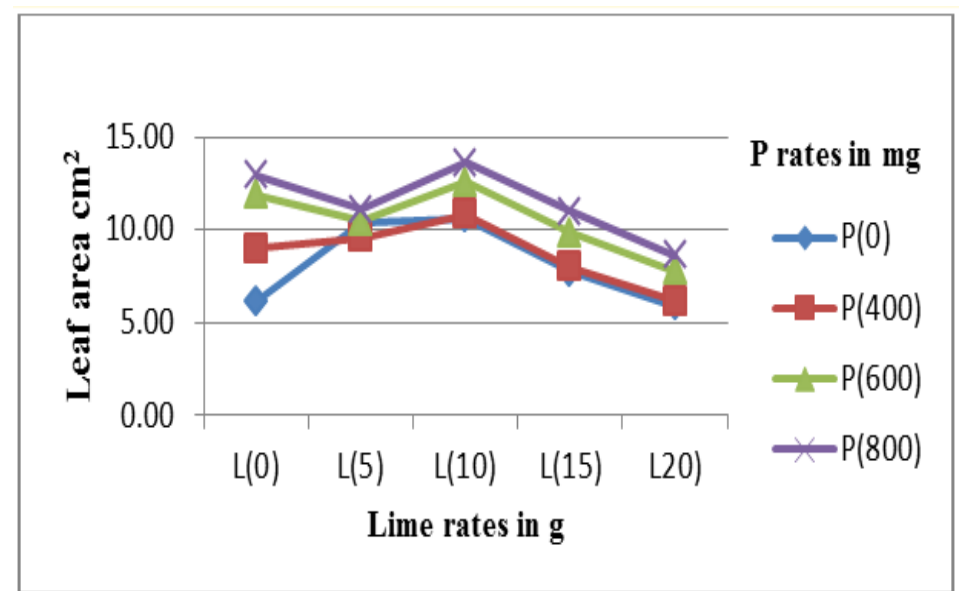

Fig 3 The interaction effects of lime and P rates on leaf area of hybrid coffee seedlings

\subsection{The Root growth of coffee seedlings}

The root growth parameters of coffee seedling significantly $(P \leq 0.01)$ affected with the application of lime and phosphorus and their interaction (Table 3). The maximum Tap root length $23.73 \mathrm{~cm}$, lateral length $9.58 \mathrm{~cm}$, lateral root number 54.07 and root volume $0.97 \mathrm{ml}$ recorded from $10 \mathrm{~g}$ lime and $800 \mathrm{mg} \mathrm{P}$ rate. While the lowest recorded form $20 \mathrm{~g}$ lime and control plot (Table 3). This could be due to at lower $\mathrm{pH}$, increased the levels of hydrogen $\left(\mathrm{H}^{+}\right)$ions occur to a great extent and $\mathrm{Al}^{3+}$ ions in the soil solution react in water (hydrolysis) and the reaction resulted in the release of $\mathrm{H}^{+}$and hydroxyl $\mathrm{Al}$ ions into the soil solution by which the $\mathrm{H}^{+}$ions released that lower the $\mathrm{pH}$ of the soil solution, making it very accessible to plants and caused toxicity. Even though this made to coffee seedling growth highly affected and reduced root growth decreases the absorption of nutrients and water and, consequently, the plant showed stunted growth (Ramos and Flores, 2008; Achalu, 2012; Habtamu, 2015). Similarly, at the highest lime rate treated plot there was high amount of calcium contents that made reduce the availability of phosphors and micro nutrients and also the calcium was toxic to seedling and displeased $\mathrm{Mg}$ and $\mathrm{K}$ from the soil solution to the exchange site.

According to Asmare et al. (2015) an increasing rate response to applied P with increased rates of added lime have been attributed to either an improved rate of $\mathrm{P}$ supply by the soil or an improved ability of the plant to absorb $\mathrm{P}$ when $\mathrm{Al}$ toxicity has been eliminated. However, as increasing level of lime from $15 \mathrm{~g}$ lime to $20 \mathrm{~g}$, the length of tap root dramatically decreased to $16.08 \mathrm{~cm}$, lateral length $4.29 \mathrm{~cm}$, lateral root number 37.46 and root volume $0.46 \mathrm{ml}$, respectively (Table 3 ).

However, an application of phosphorus showed an improved growth rate of the roots parameters (Table 3). The result revealed that the root growth increased proportionally with increasing the level of phosphorus rate 400 $\mathrm{mg} \mathrm{P}, 600 \mathrm{mg} \mathrm{P}$ and $800 \mathrm{mg} \mathrm{P}$ rates It has been reported that coffee seedlings root growth parameters such as tap root length, lateral root length and lateral root number significantly increased with the increasing rates of phosphors (Anteneh, 2015c). 
Table 3.The interaction effects of lime and phosphorus rates on root growth of hybrid coffee seedlings

\begin{tabular}{|c|c|c|c|c|c|}
\hline No & Treatment & $\begin{array}{c}\text { Tap root } \\
\text { Length }\end{array}$ & $\begin{array}{c}\text { Lateral } \\
\text { root } \\
\text { Length }\end{array}$ & $\begin{array}{c}\text { Lateral } \\
\text { root } \\
\text { Number }\end{array}$ & $\begin{array}{c}\text { Root } \\
\text { Volume }\end{array}$ \\
\hline $\mathbf{T}_{1}$ & Control & $17.26^{\mathrm{g}}$ & $5.46^{\mathrm{h}}$ & $38.06^{\mathrm{ji}}$ & $0.56^{\mathrm{hg}}$ \\
\hline $\mathbf{T}_{2}$ & 0gm Lime and $400 \mathrm{mg}$ phosphorus & $17.02^{\mathrm{g}}$ & $6.10^{\mathrm{h}}$ & $40.07^{\mathrm{hi}}$ & $0.52^{\mathrm{hi}}$ \\
\hline $\mathbf{T}_{\mathbf{3}}$ & 0gm Lime and $600 \mathrm{mg}$ phosphorus & $18.90^{\mathrm{f}}$ & $6.39^{\mathrm{gf}}$ & $41.26^{\text {hegf }}$ & $0.66^{\mathrm{d}}$ \\
\hline $\mathbf{T}_{4}$ & 0 gm Lime and $800 \mathrm{mg}$ phosphorus & $20.38^{\mathrm{d}}$ & $7.51^{\mathrm{ed}}$ & $42.62^{\mathrm{edf}}$ & $0.73^{c}$ \\
\hline $\mathbf{T}_{5}$ & $5 \mathrm{gm} \mathrm{Lime} \mathrm{and} 0 \mathrm{mg}$ phosphorus & $18.31^{\mathrm{f}}$ & $6.07^{\mathrm{g}}$ & $40.22^{\mathrm{hg}}$ & $0.59^{\text {egf }}$ \\
\hline $\mathbf{T}_{6}$ & $5 \mathrm{gm}$ Lime and $400 \mathrm{mg}$ phosphorus & $17.36^{\mathrm{g}}$ & $7.57^{\mathrm{ed}}$ & $40.64^{\text {hgf }}$ & $0.57^{\text {hgf }}$ \\
\hline $\mathbf{T}_{7}$ & 5 gm Lime and $600 \mathrm{mg}$ phosphorus & $21.52^{\mathrm{cb}}$ & $8.03^{\mathrm{cd}}$ & $44.16^{\mathrm{cd}}$ & $0.73^{c}$ \\
\hline$T_{8}$ & $5 \mathrm{gm}$ Lime and $800 \mathrm{mg}$ phosphorus & $22.00^{\mathrm{b}}$ & $8.55^{\mathrm{cb}}$ & $45.83^{\mathrm{cb}}$ & $0.83^{\mathrm{b}}$ \\
\hline $\mathbf{T}_{9}$ & $10 \mathrm{gm}$ Lime and $0 \mathrm{mg}$ phosphorus & $20.00^{\mathrm{ed}}$ & $6.57^{\mathrm{gf}}$ & $41.97^{\text {hegdf }}$ & $0.63^{\text {edf }}$ \\
\hline $\mathbf{T}_{10}$ & $10 \mathrm{gm}$ Lime and $400 \mathrm{mg}$ phosphorus & $20.90^{\mathrm{cd}}$ & $7.63^{\text {ed }}$ & $43.10^{\mathrm{ed}}$ & $0.76^{\mathrm{c}}$ \\
\hline $\mathbf{T}_{11}$ & $10 \mathrm{gm} \mathrm{Lime} \mathrm{and} 600 \mathrm{mg}$ phosphorus & $22.29^{\mathrm{b}}$ & $8.87^{\mathrm{b}}$ & $46.97^{\mathrm{b}}$ & $0.93^{\mathrm{a}}$ \\
\hline $\mathbf{T}_{12}$ & $10 \mathrm{gm}$ Lime and $800 \mathrm{mg}$ phosphorus & $23.73^{\mathrm{a}}$ & $9.58^{\mathrm{a}}$ & $54.07^{\mathrm{a}}$ & $0.97^{\mathrm{a}}$ \\
\hline $\mathbf{T}_{13}$ & 15 gm Lime and $0 \mathrm{mg}$ phosphorus & $16.03^{\mathrm{h}}$ & $4.80^{\mathrm{ij}}$ & $36.31^{\mathrm{jk}}$ & $0.47^{\mathrm{ji}}$ \\
\hline $\mathbf{T}_{14}$ & $15 \mathrm{gm} \mathrm{Lime} \mathrm{and} 400 \mathrm{mg}$ phosphorus & $17.15^{\mathrm{g}}$ & $5.32^{\text {ih }}$ & $37.49^{j}$ & $0.43^{j}$ \\
\hline $\mathbf{T}_{15}$ & $15 \mathrm{gm}$ Lime and $600 \mathrm{mg}$ phosphorus & $18.73^{\mathrm{f}}$ & $7.01^{\mathrm{ef}}$ & $40.78^{\text {hgf }}$ & $0.53^{\text {hg }}$ \\
\hline $\mathbf{T}_{16}$ & 15 gm Lime and $800 \mathrm{mg}$ phosphorus & $19.16^{\mathrm{ef}}$ & $7.43^{\text {ed }}$ & $42.62^{\text {edf }}$ & $0.64^{\text {ed }}$ \\
\hline $\mathbf{T}_{17}$ & $20 \mathrm{gm}$ Lime and $0 \mathrm{mg}$ phosphorus & $15.01^{\mathrm{i}}$ & $3.63^{1}$ & $34.39^{\mathrm{k}}$ & $0.35^{\mathrm{k}}$ \\
\hline $\mathbf{T}_{18}$ & $20 \mathrm{gm}$ Lime and $400 \mathrm{mg}$ phosphorus & $14.46^{\mathrm{i}}$ & $3.52^{1}$ & $34.47^{\mathrm{k}}$ & $0.41^{\mathrm{j}}$ \\
\hline $\mathbf{T}_{19}$ & $20 \mathrm{gm}$ Lime and $600 \mathrm{mg}$ phosphorus & $15.27^{\mathrm{ih}}$ & $3.77^{\mathrm{kl}}$ & $36.59^{\mathrm{jk}}$ & $0.44^{\mathrm{j}}$ \\
\hline \multirow[t]{3}{*}{$\mathbf{T}_{\mathbf{2 0}}$} & $20 \mathrm{gm} \mathrm{Lime} \mathrm{and} 800 \mathrm{mg}$ phosphorus & $16.08^{\mathrm{h}}$ & $4.29^{\mathrm{kj}}$ & $37.46^{\mathrm{j}}$ & $0.46^{\mathrm{ji}}$ \\
\hline & $\mathbf{S E M} \pm$ & 0.06 & 0.04 & 0.13 & 0.004 \\
\hline & CV $(\%)$ & 2.49 & 4.28 & 2.76 & 5.59 \\
\hline
\end{tabular}

Different letters within a column and row represent significant differences at $5 \%$ level

\subsection{Fresh weight of coffee seedlings}

Lime and $\mathrm{P}$ rates and its interaction significantly $(P \leq 0.01)$ affected coffee seedlings leaf, stem and root fresh weights. The maximum leaf $1.42 \mathrm{~g}$, stem $0.47 \mathrm{~g}$ and root $1.04 \mathrm{~g}$ fresh weight recorded from the treatment $10 \mathrm{~g}$ lime and $800 \mathrm{mg} P$ treated plots (Table 4). While the lowest result were recorded from control and highest lime rate.

Fageria and Moreira (2011); Felipe et al. (2014); Anteneh (2015c); Kaio et al. (2015) reported that application of lime and phosphorus at the optimum rates gave the maximum fresh shoot and root biomass than lime untreated plot.

Asmare (2015) reported that the maximum fresh shoot biomass was observed with the application of mineral $\mathrm{P}$ and lime which increased by $118 \%$ compared to the control treatment. This may be due to the lime increasing the $\mathrm{pH}$, reducing the level of exchangeable acidity and $\mathrm{Al}$ and creating a favorable environment for root growth.

An application of limes improved leaf, stem and root fresh up to $15 \mathrm{~g}$ (Table 4). Although, further application of lime rate $15 \mathrm{~g}$ and $20 \mathrm{~g}$ reduced the leaf $0.56 \mathrm{~g}$, stem $0.32 \mathrm{~g}$ and root $0.37 \mathrm{~g}$ fresh weight respectively. This was also reported by Antneh (2015b) and Kaio et al. (2015) generally leaf, stem and root fresh weight the lowest was receded from the control plot followed by the highest rate lime and $\mathrm{p}$ treated plot. On the other hand application of $400 \mathrm{mg}, 600 \mathrm{mg}$ and $800 \mathrm{mg} \mathrm{P}$ rates linearly increased root fresh weight of coffee seedlings. Whereas mineral P is an immediate source of water soluble P from the TSP and is important for coffee seedling growth which absorbs $\mathrm{P}$ starting from seedling stage. In early stages of development, seedlings absorb $\mathrm{P}$ faster from the dissolving fertilizer than from the soil and hence a high proportion of the total $\mathrm{P}$ absorbed by young plants is derived from the fertilizer application which helps to develop appropriate root growth. 
Table 4.Combined effects of lime and phosphorus on fresh weight of coffee seedlings

\begin{tabular}{|c|c|c|c|c|}
\hline No & Treatment & $\begin{array}{l}\text { Leaf fresh } \\
\text { Weight (g) }\end{array}$ & $\begin{array}{l}\text { Stem fresh } \\
\text { weight (g) }\end{array}$ & $\begin{array}{c}\text { Root fresh } \\
\text { weight(g) }\end{array}$ \\
\hline $\mathbf{T}_{1}$ & Control & $0.73^{\text {ih }}$ & $0.31^{1}$ & $0.52^{\mathrm{ih}}$ \\
\hline $\mathbf{T}_{2}$ & 0gm Lime and $400 \mathrm{mg}$ phosphorus & $0.55^{\mathrm{jk}}$ & $0.39^{\text {hij }}$ & $0.55^{\mathrm{gh}}$ \\
\hline $\mathbf{T}_{3}$ & 0gm Lime and $600 \mathrm{mg}$ phosphorus & $0.97^{\text {ffe }}$ & $0.42^{\mathrm{hg}}$ & $0.64^{\mathrm{f}}$ \\
\hline $\mathbf{T}_{4}$ & 0 gm Lime and $800 \mathrm{mg}$ phosphorus & $1.21^{\mathrm{bc}}$ & $0.45^{\text {fg }}$ & $0.72^{\mathrm{d}}$ \\
\hline $\mathbf{T}_{5}$ & $5 \mathrm{gm}$ Lime and $0 \mathrm{mg}$ phosphorus & $0.65^{\mathrm{ji}}$ & $0.38^{\mathrm{ij}}$ & $0.52^{\text {ih }}$ \\
\hline $\mathbf{T}_{6}$ & $5 \mathrm{gm}$ Lime and $400 \mathrm{mg}$ phosphorus & $0.82^{\mathrm{gh}}$ & $0.48^{\mathrm{fe}}$ & $0.53^{\text {ih }}$ \\
\hline $\mathbf{T}_{7}$ & $5 \mathrm{gm} \mathrm{Lime}$ and $600 \mathrm{mg}$ phosphorus & $0.83^{\mathrm{gth}}$ & $0.51^{\mathrm{de}}$ & $0.70^{\text {ed }}$ \\
\hline $\mathbf{T}_{8}$ & $5 \mathrm{gm} \mathrm{Lime} \mathrm{and} 800 \mathrm{mg}$ phosphorus & $1.33^{\mathrm{ba}}$ & $0.54^{\mathrm{dc}}$ & $0.79^{\mathrm{c}}$ \\
\hline $\mathbf{T}_{9}$ & $10 \mathrm{gm}$ Lime and $0 \mathrm{mg}$ phosphorus & $0.99^{\mathrm{def}}$ & $0.46^{\mathrm{f}}$ & $0.61^{\mathrm{gf}}$ \\
\hline $\mathbf{T}_{10}$ & $10 \mathrm{gm}$ Lime and $400 \mathrm{mg}$ phosphorus & $1.11^{\mathrm{dce}}$ & $0.56^{\mathrm{c}}$ & $0.70^{\text {ed }}$ \\
\hline $\mathbf{T}_{11}$ & $10 \mathrm{gm}$ Lime and $600 \mathrm{mg}$ phosphorus & $0.96^{\mathrm{gfe}}$ & $0.63^{b}$ & $0.94^{\mathrm{b}}$ \\
\hline $\mathbf{T}_{12}$ & 10 gm Lime and $800 \mathrm{mg}$ phosphorus & $1.42^{\mathrm{a}}$ & $0.74 \mathrm{a}$ & $1.04^{\mathrm{a}}$ \\
\hline $\mathbf{T}_{13}$ & $15 \mathrm{gm}$ Lime and $0 \mathrm{mg}$ phosphorus & $0.51^{\mathrm{jk}}$ & $0.32^{1 \mathrm{k}}$ & $0.48^{\mathrm{ij}}$ \\
\hline $\mathbf{T}_{14}$ & $15 \mathrm{gm} \mathrm{Lime}$ and $400 \mathrm{mg}$ phosphorus & $0.62^{\mathrm{jik}}$ & $0.31^{\mathrm{lk}}$ & $0.44^{\mathrm{kj}}$ \\
\hline $\mathbf{T}_{15}$ & $15 \mathrm{gm}$ Lime and $600 \mathrm{mg}$ phosphorus & $0.82^{\text {gfh }}$ & $0.36^{\mathrm{j}}$ & $0.54^{\mathrm{h}}$ \\
\hline $\mathbf{T}_{16}$ & 15 gm Lime and $800 \mathrm{mg}$ phosphorus & $1.14^{\mathrm{dc}}$ & $0.41^{\mathrm{hi}}$ & $0.66^{\mathrm{ef}}$ \\
\hline $\mathbf{T}_{17}$ & $20 \mathrm{gm} \mathrm{Lime}$ and $0 \mathrm{mg}$ phosphorus & $0.48^{\mathrm{k}}$ & $0.23^{\mathrm{m}}$ & $0.36^{\mathrm{m}}$ \\
\hline $\mathbf{T}_{18}$ & 20 gm Lime and $400 \mathrm{mg}$ phosphorus & $0.56^{\mathrm{jk}}$ & $0.32^{1 \mathrm{k}}$ & $0.37^{\mathrm{lm}}$ \\
\hline $\mathbf{T}_{19}$ & $20 \mathrm{gm} \mathrm{Lime}$ and $600 \mathrm{mg}$ phosphorus & $0.65^{\mathrm{ji}}$ & $0.35^{\mathrm{kj}}$ & $0.39^{\mathrm{klm}}$ \\
\hline \multirow[t]{3}{*}{$T_{20}$} & $20 \mathrm{gm}$ Lime and $800 \mathrm{mg}$ phosphorus & $0.73^{\text {ih }}$ & $0.38^{\mathrm{ij}}$ & $0.42^{\mathrm{kl}}$ \\
\hline & SEM \pm & 0.011 & 0.003 & 0.004 \\
\hline & CV (\%) & 11.28 & 5.96 & 5.92 \\
\hline
\end{tabular}

Different letters within a column represent significant differences at 5\% level

\subsection{The dry weights of shoot and root of coffee seedlings}

The maximum leaf, stem and root dry weight affected by lime and P rates the highest leaf $1.42 \mathrm{~g}$ stem $0.74 \mathrm{~g}$ and root $0.27 \mathrm{~g}$ dry weight were recorded from $10 \mathrm{~g}$ lime and $800 \mathrm{mg} P$ rates. While the lowest leaf $0.11 \mathrm{~g}$, stem $0.08 \mathrm{~g}$ and root 0.10 were recorded from $20 \mathrm{~g}$ lime treated plots (Fig 4, 5 and 6).

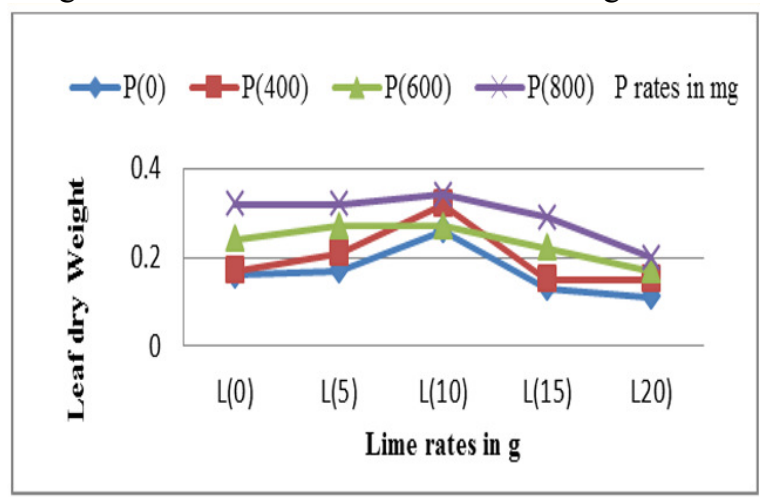

Fig 4 The interaction effects of lime and $P$ rates on Leaf dry weight of hybrid coffee

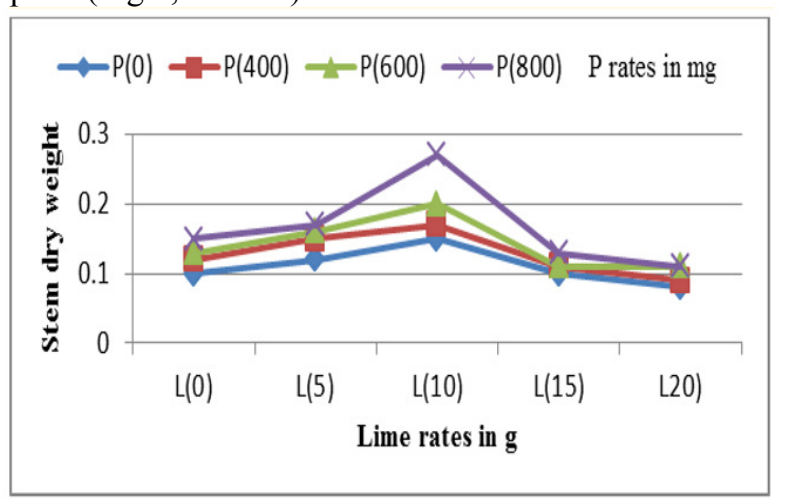

Fig 5 The interaction effects of lime and P rates on Stem dry weight of hybrid coffee 


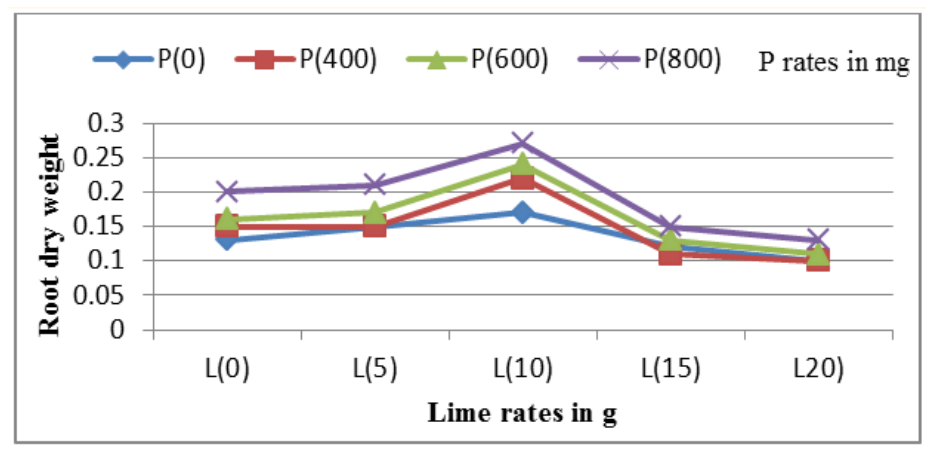

Fig 6 The interaction effects of lime and P rates on Root dry weight of hybrid coffee seedlings

\subsection{Shoot to root ratio}

The results on (Fig 7) showed that shoot to root ratio of hybrid coffee seedlings affected by the interaction lime and phosphorus rates. Whereas the maximum rate shoot to root ratio 3.40 followed by 3.18 and 2.94 observed from combined application of $10 \mathrm{~g}$ lime and $800 \mathrm{mg} \mathrm{P} ; 10 \mathrm{~g}$ lime and $600 \mathrm{mg} \mathrm{P}$ and $10 \mathrm{~g}$ lime and $400 \mathrm{mg} \mathrm{P}$ rates respectively. Taye (1998) reported that, high quality coffee seedlings with balanced shoot to root ratio need to be produced under optimum soil environments. Controversially the least shoot to root ratio 1.31 recorded from $20 \mathrm{~g}$ lime rates. Similar work to this reported by Ericsson and Ingestad (1988); Anteneh (2015c) at highest lime rates $\mathrm{P}$ was fixed with $\mathrm{Ca}^{+2}$ and limiting growth conditions occurred, while the roots share more of the total assimilates than the shoot and subsequently leading to a typical decrease in shoot to root dry matter ratio.

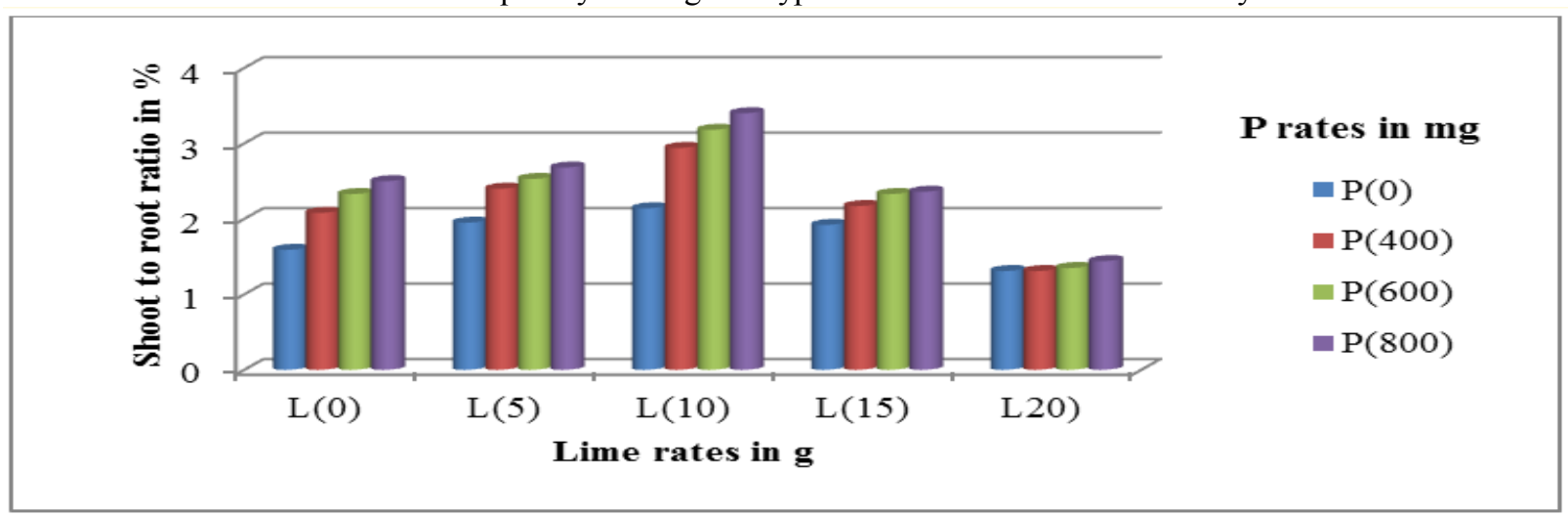

Fig 7 The effects of lime and P rates on Shoot to Root Ratio of coffee seedlings

\section{Conclusion}

Lime and phosphorus rates and their interactions were enhanced shoot and root growth performances of hybrid coffee seedlings. The interaction of $10 \mathrm{~g}$ lime and $800 \mathrm{mg} P$ rate showed significant effects on both destructive and non-destructive growth parameters of coffee seedlings.

The most shoot and root extension seedling growth parameters were significantly increased with the addition of $10 \mathrm{~g}$ lime and $800 \mathrm{mg} \mathrm{P}$ rate as compared to control and other treatments. Similarly, destructive parameters such as, tap root length, lateral length, lateral root number and root volume although showed highly significant difference among the treatments. Generally, the combined applications of $10 \mathrm{~g}$ lime and $800 \mathrm{mg}$ phosphorus rates eliminates the impacts of soil acidity problem and improves the growth parameters of hybrid coffee Seedlings at nursery stages.

\section{Acknowledgments}

The authors gratefully acknowledge The Ethiopian Institute of Agricultural research for the financial support of study.

\section{References}

Abdenna Deressa, 2013. Evaluation of Soil Acidity in Agricultural Soils of Smallholder Farmers in South Western Ethiopia. Science, Technology and Arts Research Journal, 2(2): 01-06.

Adane Buni, 2015. Effects of liming acidic soils on improving soil properties and yield of haricot bean. Journal 
of Environmental \& Analytical Toxicology, 5(1):1-4.

Achalu Chimdi, Heluf Gebrekidan, Kibebew Kibret and Abi Tadesse, 2012, Status of selected physicochemical properties of soils under different land use systems of Western Oromia, Ethiopia. Journal of Biodiversity and Environmental Sciences, 2(3): 57-71.

Achalu Chimdi, 2014. Assessment of the Severity of Acid Saturations on Soils Collected from Cultivated Lands of East Wollega Zone, Ethiopia. Science, Technology and Arts Research Journal, 3(4): 42-48.

Amaral, J.F., H.E. Martinez,B.G.Laviola,E.I.Fernandes, G.F. Filho and C.D.Cruz, 2011. Nutrients use efficiency by coffee cultivars. Ciência Rural, 41(4): 621-629.

Anteneh Netsere and Heluf Geberekidane, 2007. Response of Arabica coffee seedling to lime and phosphorus: II. Dry matter production and distribution. p. 1095-1100. In: International Conference on Coffee Science, 21st , Montpellier, 11th -15 th September 2007. ASIC,France.

Anteneh Netsere, 2015b. Response of Coffee (Coffea arabica L.) Seedlings to Lime and Phosphorus Mineral Fertilizer at Jimma, Southwestern Ethiopia. Journal of Biology, Agriculture and Healthcare, 5(13): 27-33.

Anteneh Netsere, 2015c. Dry Matter Production and Partitioning in Arabica Coffee Seedling as Affected by Lime and Phosphorus Mineral Fertilizer at Jimma, Southwestern Ethiopia. Journal of Biology, Agriculture and Healthcare, 13: 95-101

Anteneh Netsere, 2015a. Recommendation on Pre-Sowing Arabica Coffee Seed Management in Ethiopia. Journal of Biology, Agriculture and Healthcare, 5(9): 99-104.

Asmare Melese, Markku Yli-halla and Birru Yitaferu, 2015. Effects of lime, wood ash, manure and mineral P fertilizer rates on acidity related chemical properties and growth and $\mathrm{P}$ uptake of Wheat (Triticum Aestivum L.) on Acid Soil of Farta District Northwestern Highlands of Ethiopia. Int J Agric Crop Sci. 8(2):256-269.

Central Statistical Agency (CSA). 2017. Report on Area and Production of Major Crops (Vol. 1). Addis Ababa, Ethiopia.118p.

Desalegn Alemayehu, 20017. Review on Genetic Diversity of Coffee (Coffea arabica .L) in Ethiopia International Journal of Forestry and Horticulture, 3(2):18-27.

De Wispelaere, L.,V. Marcelino, A. Regassa, E. De Grave,M. Dumon, F. Mees and E.Van Ranst, 2015. Revisiting nitic horizon properties of Nitisols in SW Ethiopia. Geoderma, 243:69-79.

Eyasu Elias, 2017. Characteristics of Nitisol profiles as affected by land use type and slope class in some Ethiopian highlands. Journal of Environ Syst Res., (6)20:1-15

Fageria, N.K. and A. Moreira, 2011. The Role of Mineral Nutrition on Root Growth of Crop Plants. Advances in agronomy, 110(1):251-331.

Girma Adugna, Bayeta Bellachew, Tesfaye Shimber, Endale Taye, Taye Kufa 2008, Coffee Diversity \& Knowledge. Group discussions, synthesis and recommendations. pp: 505-510. In: Proceedings of Four Decades of Coffee Research and Development in Ethiopia, A National Workshop, 14-17 August 2007, Ghion Hotel, Addis Ababa, Ethiopia

Habtamu Admas, 2015. Reclamation of Phosphorus Fixation by Organic Matter in Acidic Soils. Global Journal of Agricultural Science, 3(6): 271-78

International Coffee Organization (ICO). 2018. Sustainability of the coffee sector in Africa. International Coffee Council 114th Session 2-6 March 2015 London, United Kingdom.

Kabata Pendias, G., H. Terelak, and C. Pietruch, 2001. Impact of soil factors on $\mathrm{Zn}$ and Cd contents in potato tubers. In: Proceedings of 6th International Conference on the Biogeochemistry of Trace Elements, Guelph, Canada.

Kaio, G., E. Lima,T. Paulo,G. Gontijo and R. Pereira, 2015. Coffee yield and phosphate nutrition provided to plants by various phosphorus sources and levels.Clenc.Agrotec39(2): 110-20.

Kebede Dinkecha and Dereje Tsegaye, 2017. Effects of liming on physicochemical properties and nutrient availability of acidic soils in Welmera Woreda, Central Highlands of Ethiopia.Chemistry and Materials Research 9(9): 30-37

Kisinyo, P.O., C.O. Othieno,S.O. Gudu, J.R.O kalebo, P.A.Opala, R.O. Ouma, E.O. Agalo, and J.J. Kebeney, 2014. Immediate and residual effects of lime and phosphorus fertilizer on soil acidity and maize production in western Kenya. Experimental Agriculture, 50(1):128-143.

Paulos Dubale,1994. Mineral Fertilizer of Coffee in Ethiopia. Institute of Agricultural Research, Addis Ababa, Ethiopia. $105 p$

Ramos H.S.G. and D.F. Roman, 2008. Comparison of two phosphate fertilizers in volcanic soils cultivated with coffee, of soconusco, chiapas, México. Agrociencia, 42(4):391-398.

Smithson, P., 1999. Special issue on phosphorus availability, uptake and cycling in tropical agroforestry. In Agroforestry Forum 9(4):37-40.

Tadesse Benti, 2017.Progress in Arabica Coffee Breeding in Ethiopia: Achievements, Challenges and Prospects. International Journal of Sciences Basic and Applied Research, 33 (2): 15-25.

Tesfaye Shimber, Alemseged Yilma, Taye Kufa, Endale Taye and Anteneh Netsere, 2005. Coffee seedlings 
management and production. Amharic version, Ethiopian Agricultural Research Organization, Addis Ababa, Ethiopia. 17pp.

The, C., H. Calba, C. Zonkeng, E.L.M.Ngonkeu and V.O.Adetimirin, 2006. Response of maize grain yield to changes in acid soil characteristics after soil amendment. Plant Soil. 284: 45-57.

Tomaz, M.A., H.E.P.Martinez, W.N.Rodrigues, R.B.Ferrari, A.A.Pereira and N.S.Sakiyama, 2011. Efficiency of absorption and utilization of boron, zinc, copper and manganese in grafted coffee seedlings. Rev. Ceres 58(1): $108-114$.

Uzoho, B.U., G.E. Osuji, E.U.Onweremadu and I.I.Ibeawuchi, 2010. Maize (Zea mays L.) response to phosphorus and lime on gas flare affected soils. Life Sci Journal, 7:77-82.

Yacob Edjamo, Tesfaye Shimber, Alemseged Yilma, Anteneh Netsere, Takele Negewo, Mohammednur Abachebsa and Bekele Bogale, 1996. Advances in coffee agronomy research in Ethiopia. p. 40-45. In Proceedings of Inter Africa Coffee organization (IACO) Workshop, 4-6 September 1995, Kampala, Uganda. 